\title{
PENERAPAN PECKING ORDER THEORY DAN KAITANNYA DENGAN \\ PEMILIHAN STRUKTUR MODAL PERUSAHAAN PADA SEKTOR MANUFAKTUR DI NEGARA INDONESIA DAN NEGARA AUSTRALIA
}

\author{
Iryuvita Januarizka Putri Radjamin \\ Bachelor Student of Management - Faculty of Economics and Business - Airlangga \\ University \\ e-mail: uv_2192@yahoo.com

\section{Made Sudana} \\ Management Department - Faculty of Economics and Business - Airlangga University \\ e-mail: imadesudana@yahoo.co.id
}

\begin{abstract}
This study aimed to determine first, the difference between the capital structures in Indonesian manufacturing company with in Australia, and secondly to determine whether manufacturing companies in Indonesia and Australia applying the packing order theory in determining the capital structure. The analysis model used is the comparative analysis between the two groups of independent samples to determine differences in capital structure manufacturing company in Indonesia with a capital structure of manufacturing companies in Australia . Meanwhile, to determine whether manufacturing companies in Indonesia and Australian applying packing order theory, used Shyam - Sunder and Meyers models . The study was conducted on 42 Australian manufacturing companies and 33 manufacturing companies in Indonesia, which is selected by purposive random sampling over the period 2006-20010. The results showed a significant difference between capital structure manufacturing companies in Indonesia and in Australia. Manufacturing companies in Indonesia using long-term debt is relatively higher compared to manufacturing companies in Australia . In addition, it was also found that in determining capital structure manufacturing companies in Indonesia to implement packing order theory, while manufacturing companies in Australia are not .
\end{abstract}

Keywords : Capital Structure, Deficit External Financing, Pecking Order Theory 


\section{Pendahuluan}

Salah satu keputusan penting yang dihadapi oleh manajer keuangan dalam menjaga kelangsungan operasi perusahaan adalah keputusan pendanaan yang berkaitan dengan pemilihan sumber dana yang akan digunakan untuk mendanai investasi yang tercermin dalam struktur modal perusahaan. Manajer keuangan harus mampu menghimpun dana, baik yang bersumber dari dalam perusahaan maupun dari luar perusahaan secara efisien, dalam arti keputusan pendanaan tersebut merupakan keputusan pendanaan yang mampu meminimalkan biaya modal yang harus ditanggung oleh perusahaan. Perbedaan karakteristik antar perusahaan dan negara akan memengaruhi keputusan struktur modal suatu perusahaan.

Negara Australia dan Indonesia memiliki beberapa perbedaan mengenai kondisi ekonomi, dan kebijakan yang ditetapkan. Di Indonesia, perusahaan dapat memperoleh kredit dari bank asal memenuhi pedoman standar kebijakan perkreditan yang ditetapkan Bank Indonesia, sedangkan di Australia kebijakan perkreditan ditetapkan oleh RBA. Berdasarkan data Badan Pusat Statistik, suku bunga kredit di Indonesia sejak tahun 2006 terus menurun dari 15,36\% hingga 13,06\% di tahun 2010, di Australia juga menunjukkan penurunan suku bunga dari tahun ke tahun, tetapi masih lebih rendah dari Indonesia, yaitu $6.25 \%$ di tahun 2006 dan turun menjadi $4.75 \%$ di tahun 2010. Tingkat suku bunga di Autralia jauh lebih rendah karena inflasi di negara tersebut juga jauh lebih rendah. Jumlah bank di Indonesia mencapai 131 bank termasuk 7 bank milik pemerintah. Di Australia terdapat 62 bank, yang didominasi oleh 4 bank. Dilihat dari banyaknya bank, Indonesia memiliki lebih banyak alternatif sumber pendanaan dari eksternal yaitu bank-bank tersebut. Dilihat dari suku bunga perusahaan di Australia lebih diuntungkan dengan rendahnya suku bunga kredit sehingga memungkinkan menggunakan utang sebagai sumber pendanaan.

Persaingan industri manufaktur di Indonesia juga semakin ketat, karena perkembangan perusahaan manufaktur yang cukup pesat, dan banyaknya produk impor yang dengan mudahnya masuk ke pasar Indonesia dan menjadi alternatif pilihan konsumen di Indonesia. Maraknya produk-produk impor yang masuk secara ilegal di Indonesia juga menjadi hambatan bagi perusahaan domestik untuk menguasai pasar. Meski di Australia tarif impor juga termasuk rendah sebagai hasil dari perjanjian dagang dan potongan tarif unilateral, dan pengawasan barang impor ilegal lebih ketat dibandingkan di Indonesia, sehingga perusahaan domestik Australia tetap menguasai pasar.

Pentingnya pemilihan struktur modal dalam setiap perusahaan menyebabkan banyak dikembangkannya teori-teori mengenai struktur modal. Teori yang dikaji pada penelitian ini adalah pecking order theory, yang merupakan salah satu teori tentang struktur modal yang menyatakan bahwa penggunaan dana internal lebih didahulukan dibandingkan dengan penggunaan dana yang bersumber dari eksternal, namun ketika dana yang berasal dari laba ditahan (retained earnings) masih belum mencukupi, maka perusahaan akan mencari pendanaan dari eksternal, yaitu berupa utang dan alternatif terakhir adalah menerbitkan saham.

Rata-rata rasio financial leverage perusahaan-perusahaan manufaktur di Australia yang diukur menggunakan rasio utang jangka panjang terhadap total ekuitas cenderung lebih rendah daripada rasio financial leverage perusahaan-perusahaan manufaktur di Indonesia dalam periode 2006-2010 yaitu 75,85\% di Indonesia dan 33,33\% di Australia. Rasio tertinggi 
financial leverage di perusahaan manufaktur Indonesia mencapai 101,9\% di tahun 2009, dan hanya 42,37\% di perusahaan manufaktur Australia tahun 2008. Hal ini menunjukkan bahwa struktur modal perusahaan di Indonesia secara relatif menggunakan utang jangka panjang lebih banyak daripada perusahaan di Australia.

Hasil penelitian Singh dan Hamid (1992) dan Singh (1995) menemukan bahwa perusahaan di negara berkembang cenderung lebih banyak menggunakan saham dibanding utang dalam pendanaan perusahaan. Begitu pula dengan hasil penelitian Huang dan Song (2002) yang meneliti keputusan financial leverage pada 799 perusahaan berprofitabilitas tinggi di Cina memiliki utang yang rendah. Penelitian Huang dan Song (2002), Singh dan Hamid (1992), dan Singh (1995) ini berbeda dengan yang terjadi di Indonesia yaitu penggunaan utang secara relatif lebih banyak dibandingkan saham.

Di Indonesia, penelitian mengenai teori pecking order yang dilakukan Hutagaol (2002), pada perusahaan non-keuangan dan non-properti yang terdaftar di BEI tahun 1994-1996. Hasil penelitian menemukan bahwa teori pecking order dapat menjelaskan pengaruh defisit keuangan terhadap penerbitan utang jangka panjang, dan perusahaan cenderung menggunakan utang jangka panjang dibanding penerbitan saham.

Penelitian Huang dan Song (2002), mengemukakan bahwa struktur modal perusahaan di negara berkembang tidak mengikuti teori pecking order berdasarkan model Shyam-Sunder dan Myers (1999). Penelitian ini ingin mengetahui perbedaan kebijakan struktur modal perusahaan manufaktur di Indonesia dan Australia, dan perusahaan di negara mana yang mengikuti teori pecking order dalam menentukan kebijakan struktur modal.

\section{Permasalahan}

Berdasarkan pada fenomena yang telah dijelaskan pada pendahuluan, permasalahan yang dikaji pada penelitian ini adalah:

1. Apakah terdapat perbedaan struktur modal antara perusahaan manufaktur di Indonesia dengan perusahaan manufaktor di Australia?

2. Apakah perusahaan manufaktur di Indonesia dan Australia menerapkan packing order theory dalam menentukan struktur modal ?

\section{Tinjauan Pustaka}

\section{Pengertian Stuktur Modal}

Struktur modal adalah proporsi antara utang jangka panjang dengan modal sendiri perusahaan yang tercermin pada neraca di sisi pasiva. Menurut Rodoni \& Ali (2010) struktur modal adalah proporsi pembiayaan permanen perusahaan menggunakan dana yang diperoleh dari kombinasi yang utang jangka panjang, modal saham biasa, modal saham preferen, dan akumulasi laba ditahan.

Menurut Bambang Riyanto (2001:22) struktur modal ini dibedakan dengan struktur finansial (struktur keuangan). Struktur modal hanya merupakan sebagian dari struktur keuangan perusahaan. Struktur keuangan adalah cara bagaimana perusahaan membiayai aktivanya, 
yang terdiri dari utang jangka pendek, utang jangka panjang, dan modal pemegang saham. Struktur modal adalah pembelanjaan permanen yang mencerminkan perimbangan antara utang jangka panjang dengan modal sendiri.

Capital structure $=\frac{\text { Total Long Term Debf }}{\text { Total Equity }} \times 100 \%$

Rasio diatas ini menunjukkan seberapa besar perbadingan utang jangka panjang dengan total ekuitas. Semakin besar rasio ini mengindikasikan semakin besar penggunaan utang jangka panjang dibandingkan dengan penggunaan ekuitas dalam pendanaan perusahaan, dan sebaliknya. Setiap perusahaan berusaha untuk mencapai struktur modal yang optimal supaya dapat memaksimalkan nilai perusahaan tersebut. Kombinasi tersebut akan memengaruhi risiko keuangan perusahaan dan nilai perusahaan. Cassar, et al. (2003), mengemukakan bahwa perusahaan yang telah mengalami pertumbuhan pesat akan membutuhkan dana yang meningkat sejalan dengan tingkat pertumbuhan, untuk memenuhi kebutuhan dana tersebut yang dapat dipenuhi dengan utang atau modal sendiri.

\section{Teori Stuktur Modal}

Teori struktur modal telah mengalami perkembangan dari waktu ke waktu. Perkembangan teori struktur modal dimulai dari kemunculan The Net Income Approach (pendekatan penghasilan bersih), The Net Operating Income Approach (pendekatan penghasilan operasional bersih), dan Traditional Approach (pendekatan tradisional).

Pada tahun 1958, teori struktur modal mengalami perkembangan, dengan dikemukakannya teori struktur modal modern oleh Franco Modigliani \& Merton Miller (MM) yang menggunakkan 2 proposisi. Munculnya teori MM ini sangat berguna bagi perkembangan teori struktur modal, walaupun teori ini kurang relevan karena penggunaan asumsi pasar modal sempurna, sedangkan pada kenyataannya pasar modal adalah tidak sempurna. Bukti ketidaksempurnaan ini antara lain adalah adanya pajak, biaya transaksi, informasi yang tidak simetris, adanya biaya kebangkrutan, dan terjadinya perubahan biaya utang ketika proporsi jumlah hutang berubah (Husnan,2000). Oleh karena itu pengembangan teori struktur modal selanjutnya dengan mengubah asumsi, sehingga semakin mendekati kondisi riil. Kelemahan teori-teori sebelumnya diperbaiki oleh kemunculan Trade Off Theory dan Pecking Order Theory.

\section{Trade Off Theory}

Teori ini dinamakan trade off karena beranggapan bahwa struktur modal optimal ditentukan oleh trade off antara tax shield of leverage dengan cost of financial distress dan agency cost of leverage (Myers \& Majluf,1984). Menurut trade off theory, stuktur modal optimal dicapai dengan menyeimbangkan antara manfaat dan biaya yang harus ditanggung atas penggunaan utang (Brigham, et al, 2001).

Tax shield adalah manfaat penggunaan utang yang timbul karena pajak dibebankan pada laba perusahaan setelah dikurangi bunga, sehingga pembayaran bunga utang dapat mengurangi total beban pajak perusahaan. Semakin besar utang yang digunakkan perusahaan, semakin besar tax shield dan semakin besar nilai perusahaan. Besar kecilnya tax shield diukur dengan menggunakan : 
Berdasarkan persamaan tersebut berarti semakin besar penggunaan utang, maka semakin besar penghematan pajak yang diperoleh perusahaan, dan sebaliknya. Namun demikian penggunaan utang yang semakin besar juga akan berdampak pada peningkatan risiko perusahaan mengalami kesulitan keuangan (financial distress) atau bahkan kebangkrutan.

Financial distress adalah suatu tekanan keuangan yang menyertai penggunaan utang perusahaan. Tekanan keuangan ini terjadi apabila perusahaan mengalami kesulitan memenuhi kewajibannya kepada kreditor, sehingga mengakibatkan perusahaan terancam bangkrut. Semakin besar utang yang digunakkan perusahaan, risiko kebangkrutan yang dihadapi perusahaan juga semakin besar, sehingga akan menurunkan nilai perusahaan, dan sebaliknya. Dengan demikian menurut trade off theory, struktur modal optimal akan tercapai ketika nilai perusahaan maksimal pada tingkat penggunan utang tertentu.

\section{Pecking Order Theory}

Teori pecking order menyarankan perusahaan memiliki preferensi dalam memilih sumber pendanaan dengan mempertimbangkan biaya termurah dan risiko paling kecil. Berdasarkan pecking order theory, tidak terdapat struktur modal yang optimal. Teori ini menyatakan bahwa perusahaan lebih menyukai penggunaan dana internal daripada eksternal dalam membiayai pengembangan usahanya, sehingga urutan atau hierarki pendanaan berdasarkan teori pecking order adalah sebagai berikut :

a) Pendanaan internal yang berasal dari laba ditahan

b) Penggunaan utang dengan menerbitkan obligasi

c) Penerbitan saham

Teori ini beranggapan bahwa perusahaan yang menguntungkan (profitable) lebih sedikit menggunakan utang. Brealey, et al. (2001:446) menjelaskan mengapa kebanyakan perusahaan yang profitable lebih sedikit menggunakan utang, bukan karena rendahnya target debt ratio, tetapi karena perusahaan baru menggunakan dana dari luar (penerbitan utang atau saham) setelah dana internal tidak mencukupi. Teori pecking order ini juga tidak mengesampingkan bahwa pajak dan financial distress adalah faktor penting dalam pemilihan struktur modal.

Teori ini berawal dari adanya informasi asimetris antara external shareholders dengan orang dalam perusahaan yang memiliki informasi lebih baik mengenai kondisi perusahaan yang sebenarnya, dan ketidaksempurnaan pasar yang memengaruhi sisi penawaran dari pendanaan, seperti ketersediaan dan biaya yang berbeda atas berbagai sumber pendanaan (Myers \& Majluf 1984). Hal ini menyebabkan investor tidak dapat mengetahui nilai intrinsik saham baru yang diterbitkan perusahaan. Pemegang saham juga tidak akan menyukai penerbitan saham baru karena akan menurunkan earning per share. Solusi bagi manajer adalah mendanai investasi dengan retained earning, dan jika pendanaan eksternal diperlukan, perusahaan akan menggunakan utang yang biaya penerbitannya paling rendah. 
Asumsi lain dalam teori ini adalah ;

1) Perusahaan menyukai internal financing (pendanaan dari hasil operasi perusahaan).

2) Perusahaan mencoba menyesuaikan rasio pembagian dividen yang ditargetkan dengan berusaha menghindari perubahan pembayaran deviden secara drastis.

3) Kebijakan deviden yang relatif segan untuk diubah, disertai dengan fluktuasi profitabilitas dan kesempatan investasi yang tidak bisa diduga, mengakibatkan dana hasil operasi kadang-kadang melebihi kebutuhan dana untuk investasi, meskipun pada kesempatan yang lain, mungkin kurang. Apabila dana hasil operasi kurang dari kebutuhan investasi, maka prusahaan akan mengurangi saldo kas atau menjual sekuritas yang dimiliki.

4) Apabila pendanaan dari luar (external financing) diperlukan, maka perusahaan akan menerbitkan sekuritas yang paling "aman" terlebih dahulu yaitu dimulai dengan penerbitan obligasi, kemudian diikuti oleh sekuritas yang berkarakteristik opsi (seperti obligasi konversi), dan terakhir, apabila masih belum mencukupi, perusahaan menerbitkan saham baru.

Pendanaan internal memiliki keuntungan, yaitu tidak memerlukan biaya penerbitan dan tidak perlu memberikan informasi mengenai kondisi keuangan perusahaan, seperti kesempatan investasi yang potensial dan keuntungan yang diharapkan bila kesempatan investasi tersebut diambil. Prioritas pendanaan ini dibentuk berdasarkan pendanaan mana yang paling murah.

Ada empat alasan yang mendasari mengapa teori pecking order mengutamakan utang daripada ekuitas apabila pendanaan ekternal dibutuhkan.

Pertama, investor mederita kerugian karena adanya asimetri informasi antara manajer dengan investor (Aerlof, 1970 dalam Siregar 2005). Dengan adanya asimetri informasi, emisi saham baru diinterpretasikan oleh pasar sebagai berita buruk karena manajer hanya tertarik melakukan emisi saham baru jika saham perusahaan overpriced (Myers \& Majluf,1984). Berbagai bukti empiris sudah menunjukkan bahwa pengumuman emisi saham baru menyebabkan harga saham turun secara tajam (Asquith \& Mullins,1986; Masulis \& Korwar, 1986; Mikkelson \& Partch, 1986 dalam Siregar 2005).

Kedua, emisi utang dan emisi saham sama-sama membutuhkan biaya transaksi bagi perusahaan. Akan tetapi, Baskin (1989) menemukan bahwa biaya transaksi emisi utang lebih rendah daripada biaya transaksi emisi saham. Karena itulah perusahaan lebih tertarik memperoleh dana ekternal dari utang daripada ekuitas.

Ketiga, menurut Babu \& Jain (1998), perusahaan mendapatkan manfaat pajak dengan mengeluarkan utang. Manfaat ini diperoleh oleh perusahaan karena biaya bunga dapat dibebankan sebagai biaya dalam perhitungan pajak, sehingga pajak yang harus dibayar berkurang.

Keempat, dengan menggunakan utang, perusahaan akan lebih dikontrol oleh lembaga (kreditur) yang ikut mengawasi keadaan finansial perusahaan. Dengan demikian manajemen akan lebih berhati-hati dalam menggunakan utangnya. 
Pada penelitian yang dilakukan oleh Shyam-Sunder \& Myers (1999), dijelaskan bahwa dalam bentuk yang paling sederhana, pecking order model pada pendanaan perusahaan menjelaskan bahwa ketika arus kas internal perusahaan tidak cukup untuk mendanai investasi, perusahaan akan menerbitkan utang. Saham tidak akan diterbitkan, kecuali biaya financial distress perusahaan tinggi dan perusahaan hanya dapat menerbitkan junk debt. Model pecking order yang digunakan oleh Shyam-Sunder \& Myers (1999) adalah sebagai berikut :

$\Delta \mathrm{D}_{\mathrm{it}=} \alpha+\beta_{\mathrm{POT}} \mathrm{DEF}_{\mathrm{it}}+\varepsilon_{\mathrm{it}}$

Keterangan :

$\Delta \mathrm{D}_{\mathrm{it}} \quad=$ Perubahan penerbitan utang jangka panjang perusahaan i pada tahun $\mathrm{t}$

$\alpha \quad=$ Nilai intercept

$\beta_{\mathrm{POT}}=$ Nilai koefisien regresi

$\varepsilon \quad=$ Error term

$\Delta D_{i, t}=\frac{\text { LTDebt }_{i, t}-\text { LTDebt }_{i, t-1]}}{\text { Tofal Assets }}$

Keterangan :

LTDebt $_{\mathrm{i}, \mathrm{t}}=$ Utang jangka panjang perusahaan $\mathrm{i}$ pada tahun $\mathrm{t}$

LTDebt $_{\mathrm{i},(\mathrm{t}-1)} \quad=$ Utang jangka panjang perusahaan i pada tahun $\mathrm{t}-1$

Total Assets $\mathrm{i}_{\mathrm{i}, \mathrm{t}}=$ Total aset perusahaan $\mathrm{i}$ pada tahun $\mathrm{t}$

$D E F_{i, t}=\frac{\text { DV }_{i, t}+l_{i, t}-\Delta W_{i, t}-C_{i, t}}{\text { Total Assetsitit }}$

Keterangan :

$\mathrm{DEF}_{\mathrm{it}}=$ Deficit external financing perusahaan i pada tahun $\mathrm{t}$

DIV $_{\text {it }}=$ Pembayaran dividen kas perusahaan $\mathrm{i}$ pada tahun $\mathrm{t}$

$\mathrm{I}_{\mathrm{it}} \quad=$ Arus kas bersih dari aktivitas investasi perusahaan i pada tahun $\mathrm{t}$

$\Delta \mathrm{W}_{\mathrm{it}}=$ Perubahan modal kerja perusahaan i pada tahun $\mathrm{t}$ ( perubahan modal

kerja operasional + perubahan kas dan setara kas + perubahan utang lancar )

$\mathrm{C}_{\mathrm{it}}=$ Arus kas bersih dari aktivitas operasi perusahaan i pada tahun $\mathrm{t}$ 
Deficit external financing mengukur perbedaan antara kas yang dihasilkan oleh perusahaan dengan total pengeluaran modal, dividen, dan perubahan modal kerja. Deficit external financing yang positif menggambarkan perusahaan kekurangan kas, sehingga dibutuhkan sumber pendanaan eksternal, sedangkan jika bernilai negatif, berarti kelebihan kas, yang akan dipergunakan untuk membayar utang atau membeli kembali ekuitas perusahaan (ShyamSunder \& Myers, 1999). Semua komponen variabel DEF merupakan variabel eksogen selama utang dapat diterbitkan tanpa perlu menerbitkan saham.

Sesuai dengan teori pecking order, perusahaan yang mengalami defisit akan menggunakan sumber dana eksternal berupa utang kemudian saham. Teori pecking order dapat diuji menggunakan model Shyam-Sunder \& Myers (1999). Penambahan defisit perusahaan harus sejalan dengan penambahan penerbitan utang baru perusahaan (Frank \& Goyal, 2003). Koefisien regresi menjelaskan seberapa besar defisit keuangan memengaruhi penerbitan utang. Apabila perusahaan menerapkan pecking order theory dalam penentuan struktur modal maka, koefisien regresi $(\beta)$ positif mendekati 1 dan konstanta $(\alpha)$ mendekati 0 (Shyam-Sunder $\&$ Myers,1999). Hal ini berarti jika perusahaan sepenuhnya menerapkan pecking order theory maka koefisien regresi $=1$, artinya jika perusahaan mengalami defisit keuangan sebesar Rp 1000, maka perusahaan akan menambah utang sebesar Rp 1000.

\section{Penelitian Sebelumnya}

Penentuan struktur modal perusahaan sekarang masih menjadi isu yang sangat penting dalam manajemen keuangan. Banyak penelitian empiris dilakukan untuk menentukan struktur modal di negara-negara berkembang dan maju diantaranya.

1. Ni \& Yu (2008), melakukan pengujian pecking order theory pada perusahaan di Cina dan Taiwan. Penelitian ini menggunakan model Shyam-Sunder \& Myers (1999) untuk membuktikan penerapan teori pecking order. Hasil dari penelitian ini menunjukkan perusahaan di kedua negara tidak menerapkan teori pecking order dalam keputusan struktur modal.

2. Glen \& Singh (2004), melakukan perbandingan struktur modal di negara maju dan berkembang. Penelitian ini menggunakan 8000 perusahaan manufaktur di 44 negara dengan tahun penelitian 1994-2000. Hasilnya adalah perusahaan di negara berkembang memiliki tingkat utang lebih rendah, aset tetap yang lebih tinggi, dan ROA maupun ROE yang lebih rendah dibandingkan dengan negara maju.

3. Frank \& Goyal (2002), melakukan pengujian pecking order theory pada perusahaan di Amerika dari tahun 1971-1998. Hasil yang ditemukan dari pengujian ini adalah perusahaan di Amerika lebih menggunakan dana eksternal berupa penerbitan saham ketika terjadi financing deficit.

4. Andi (2012), menguji penerapan teori pecking order pada perusahaan non-keuangan di Indonesia menggunakan model Shyam-Sunder \& Myers. Pada penelitian ini ditemukan bahwa defisit keuangan dan penambahan utang jangka panjang memiliki pengaruh yang positif dan signifikan. Perusahaan ukuran kecil maupun besar memiliki pengaruh positif, namun defisit keuangan memiliki pengaruh yang lebih besar terhadap penerbitan utang jangka panjang pada perusahan ukuran besar. 


\section{Hipotesis}

Keputusan struktur modal suatu perusahaan dipengaruhi oleh faktor internal dan eksternal perusahaan. Faktor internal berkaitan dengan karakteristik perusahaan, seperti profitabilitas, struktur aktiva, ukuran perusahaan, sifat manajemen dan sebagainya, sedangkan faktor eksternal terkait dengan karakteristik negara tempat perusahaan berada, seperti tingkat inflasi, suku bunga, pertumbuhan ekonomi dan sebagainya. Perusahaan manufaktor di Indonesia berbeda dengan perusahaan manufaktur di Australia, yaitu perusahaan di Indonesia cedrung bersifat padat karya, sedangkan perusahaan di Australia cendrung bersifat padat modal. Sementara itu negara Indonesia masih tergolong negara berkembang, sedangkan Australia sudah termasuk negara maju. Kondisi ini akan berdampak pada perbedaan keputusan struktur modal perusahaan di Indonesia dan di Australia.

$\mathrm{H}_{1}$. Terdapat perbedaan antara struktur modal perusahaan manufaktur di Indonesia dan struktur modal perusahaan manufaktur di Australia

Berdasarkan teori packing order, perusahaan lebih menyukai penggunaan dana internal daripada eksternal dalam membiayai pengembangan usahanya. Hal ini berimplikasi prioritas pemenuhan kebutuhan dana berdasarkan pecking order adalah sebagai berikut : pertama pendanaan internal yang berasal dari laba ditahan, kedua penggunaan utang, dan ketiga penerbitan saham. Teori ini beranggapan bahwa perusahaan yang menguntungkan (profitable) lebih sedikit menggunakan utang dan sebaliknya perusahaan yang tidak menguntungkan lebih banyak menggunakan utang. Apabila perusahaan telah menggunakan seluruh sumber dana interal namun perusahaan masih membutuhkan tambahan dana atau perusahaan mengalami defisit maka berdasarkan teori packing order perusahaan harus menerbitkan utang, dan semaikin besar deficit maka tambahan utangnya akan semakin besar.

$\mathrm{H}_{2}$. Defisit pendanaan eksternal (DEF) perusahaan manufaktur di Indonesia dan Australia $(\mathrm{DEF})$ berpengaruh positif terhadap penambahan utang $(\Delta \mathrm{D})$.

\section{Metode Penelitian}

\section{Identifikasi Variabel}

Berdasarkan permasalahaan, model analisis dan hipotesis penelitian maka variabel-variabel penelitian dapat diidentifikasi sebagai berikut :

Permasalahan 1

Variabel yang dianalisis adalah struktur modal perusahaan manufaktur di Indonesia dan di Australia

Permasalahan 2

1. Variabel terikat (dependent variable) model analisis ini adalah perubahan utang jangka panjang bersih perusahaan manufaktur di Indonesia dan Australia

2. Variabel bebas (independent variable) adalah deficit external financing (DEF) 


\section{Definisi Operasional Variabel}

1) Struktur modal, merupakan perbandingan antara utang jangka panjang dengan modal sendiri pada akhir tahun yang diukur dengan rumus 1)

2) Penambahan utang jangka panjang adalah perubahan utang jangka panjang dari periode $\mathrm{t}-1$ ke periode $\mathrm{t}$ yang diukur menggunakan rumus 4)

3) Deficit external financing merupakan kebutuhan dana eksternal perusahaan yang diukur dengan perbedaan antara kas yang dihasilkan perusahaan dengan kas yang dikeluarkan perusahaan untuk fixed assets, dividen, dan perubahan modal kerja. Deficit external financing dihitung dari rumus 5)

Prosedur Penentuan Sampel

Metode penentuan jumlah sample dalam penelitian ini menggunakan rumus Slovin, sebagai berikut :

$$
n=\frac{N}{1+N(e)^{2}}
$$

$$
\begin{aligned}
& \text { Keterangan : } \\
& \mathrm{n}=\text { ukuran sampel } \\
& \mathrm{N}=\text { ukuran populasi } \\
& \mathrm{e}=\text { nilai presisi }(15 \%)
\end{aligned}
$$

Dengan menggunakan rumus tersebut, maka jumlah sampel sebesar 33 prusahaan manufaktur Indonesia dan 42 perusahaan manufaktur Australia. Metode pengambilan sample dalam penelitian ini menggunakan purposive random sampling. Kriteria yang akan ditetapkan untuk pemilihan sampel adalah sebagai berikut :

1. Perusahaan manufaktur yang terdaftar dan menerbitkan laporan keuangan di Bursa Efek Indonesia dan Australian Stock Exchange selama periode penelitian yaitu tahun 2006 hingga tahun 2010

2. Laporan keuangan yang berakhir per 31 Desember di Indonesia dan per 31 Juni di Australia

Setelah dilakukan pemilihan sampel secara purposive kemudian untuk menentukan perusahaan -perusahaan mana yang dipilih dilakukan dengan teknik random menggunakan program SPSS 18, sehingga didapatkan 33 perusahaan manufaktur Indonesia dan 42 perusahaan manufaktur Australia. 


\section{Model Analisis}

Model analisis dalam penelitian ini adalah ada 2, yaitu :

Permasalahan pertama : Menggunakan model uji beda rata-rata independent sample

$$
t=\frac{C_{\text {Indo }}-C S_{\text {Aus }}}{\sqrt{\frac{S D_{C S} \text { indo }}{n_{\text {lndo }}}+\frac{S D_{\text {CS indo }}}{n_{\text {Indo }}}}}
$$

Keterangan :

$\overline{C S}_{\text {Indo }}=$ Struktur modal perusahaan manufaktur di Indonesia

$\overline{C S}_{\text {Aus }} \quad=$ Struktur modal perusahaan manufaktur di Australia

$\mathrm{SD}_{\mathrm{CS} \text { Indo }}=$ Standar deviasi struktur modal perusahaan manufaktur Indonesia

$\mathrm{SD}_{\mathrm{CS} \text { Aus }}=$ Standar deviasi struktur modal perusahaan manufaktur Australia

$\mathrm{n} \quad=$ Jumlah sampel

Permasalahan kedua : Menggunakan model Shyam-Sunder \& Myers

Mengacu pada rumus 3.

$$
\Delta \mathrm{D}_{\mathrm{it}}=\alpha+\beta_{\mathrm{POT}} \mathrm{DEF}_{\mathrm{it}}+\varepsilon_{\mathrm{it}}
$$

Keterangan:

$\Delta \mathrm{D}_{\mathrm{it}} \quad=$ Perubahan penerbitan utang jangka panjang perusahaan i pada tahun $\mathrm{t}$

$\alpha=$ Nilai intercept

$\beta_{\mathrm{POT}}=$ Nilai koefisien regresi

$\varepsilon \quad=$ Error terml 


\section{Hasil dan Pembahasan}

\section{Deskripsi Hasil Penelitian}

Diskripsi variabel yang diteliti baik untuk perusahaan manufaktur di Indonesia maupun perusahaan manufaktur di Australia, secara ringkas dipaparkan pada Tabel 4.1. berikut ini.

Berdasarkan Tabel 4.1, dapat dilihat bahwa nilai rata-rata variabel capital structure perusahaan manufaktur Indonesia sebesar 57,23\% lebih tinggi daripada perusahaan manufaktur di Australia sebesar 29,06\%. Perusahaan manufaktur di Indonesia proporsi penggunaan utang jangka panjang dibandingkan dengan modal sendirinya lebih besar dibandingkan dengan perusahaan manufaktur di Australia.

Variabel perubahan utang jangka panjang perusahaan manufaktur di Indonesia memiliki nilai rata-rata sebesar $-0,32 \%$, sedangkan di Australia adalah $1,02 \%$. Tanda negatif menunjukkan adanya pengurangan utang di perusahaan manufaktur Indonesia, sedangkan tanda positif menunjukkan adanya penambahan utang di perusahaan manufaktur Australia.

Deficit external financingl maximum di Australia mencapai 233,14\% sedangkan di Indonesia hanya $62,83 \%$, tanda positif pada variabel ini menunjukkan kekurangan kas. Rata-rata variabel DEF perusahaan manufaktur di Australia lebih kecil daripada rata-rata perusahaan manufaktur di Indonesia, yaitu $-11,72 \%$ di Australia dan $-13,39 \%$ di Indonesia. Kedua ratarata DEF memiliki nilai negatif yang menunjukkan bahwa perusahaan manufaktur di Indonesia dan Australia memiliki kelebihan kas

Tabel 4.1

Deskripsi Statistik Perusahaan Manufaktur Indonesia dan Australia 2006 - 2010

\begin{tabular}{|c|c|c|c|c|c|}
\hline \multicolumn{6}{|l|}{ Indonesia } \\
\hline Variabel & $\mathrm{N}$ & Minimum & Maximum & Mean & Std. Deviasi \\
\hline Capital Structure & 165 & $1,59 \%$ & $526,39 \%$ & $57,23 \%$ & $70,73 \%$ \\
\hline Perubahan Utang & 165 & $-101,03 \%$ & $77,31 \%$ & $-0,32 \%$ & $16,16 \%$ \\
\hline DEF & 165 & $-80,04 \%$ & $62,83 \%$ & $-13,39 \%$ & $19,35 \%$ \\
\hline \multicolumn{6}{|l|}{ Australia } \\
\hline Capital Structure & 210 & $0,02 \%$ & $144,84 \%$ & $29,06 \%$ & $26,84 \%$ \\
\hline Perubahan Utang & 210 & $-212,66 \%$ & $120,02 \%$ & $1,02 \%$ & $19,60 \%$ \\
\hline DEF & 210 & $-197,03 \%$ & $233,14 \%$ & $-11,72 \%$ & $43,19 \%$ \\
\hline
\end{tabular}

Sumber : Hasil output Eviews 6.0 yang diolah 


\section{Analisis Model dan Pengujian Hipotesis}

\section{Analisis Perbedaan Struktur Modal Perusahaan Manufaktur Indonesia dengan Australia}

Untuk mengetahui perbedaan struktur modal perusahaan manufaktur di Indonesia dengan Australia dilakukan uji beda rata-rata dengan menggunakan independent sample t-test. Dalam melakukan uji beda alat yang digunakan software SPSS 18. Hasil uji beda rata-rata struktur modal perusahaan manufaktur di Indonesia dengan Australia dipaparkan pada Tabel 4.2

\section{Tabel 4.2}

Hasil uji independent sample t-test pada capital structure

\begin{tabular}{|c|c|c|c|c|}
\hline Capital Structure & $\begin{array}{c}\text { Mean Capital } \\
\text { Structure (\%) }\end{array}$ & Selisih (\%) & Sig. & Keterangan \\
\hline Indonesia & 57,226 & & & $\begin{array}{c}\text { Terdapat } \\
\text { perbedaan } \\
\text { signifikan }\end{array}$ \\
\hline Australia & 29,059 & 28,167 & 0,007 & \\
\hline
\end{tabular}

Sumber : Hasil output SPSS 18 yang diolah

Berdasarkan Tabel 4.2 menunjukkan hasil uji independent t-test dengan tingkat signifikansi sebesar $0,007<0,05$, sehingga dapat disimpulkan bahwa terdapat perbedaan struktur modal antara perusahaan manufaktur di Indonesia dengan Australia. Secara relative perusahaan manufaktur di Indonesia menggunakan utang jangka panjang yang lebih besar dibandingkan dengan perusahaan manufaktur di Australia. Perbedaan struktur modal ini dikarenakan adanya perbedaan karakteristik antara kedua negara Di negara Australia perusahaan manufakturnya lebih padat modal dibandingkan perusahaan manufaktur di Indonesia yang lebih padat tenaga kerja. Hal ini berpengaruh terhadap keputusan pendanaan yang lebih mengutamakan modal sendiri dibandingkan dengan utang. Investasi jangka panjang dalam barang modal dibiayai dengan modal jangka panjang yaitu dengan menerbitkan saham. Hasil penelitian ini berbeda dengan hasil penelitian Singh dan Hamid (1992) dan Singh (1995) yang menemukan bahwa perusahaan di negara berkembang secara relatif cenderung lebih banyak menggunakan saham dibanding di negara maju.

\section{Analisis Penerapan Pecking Order Theory di Perusahaan Manufaktur Indonesia dengan Australia}

Berdasarkan teknik estimasis model regresi data panel, dapat menggunakan tiga metode yaitu Pooled Least Square (PLS), Fixed Effect Model (FEM), dan Random Effect Model (REM). Dari ketiga metode tersebut, terlebih dahulu ditentukan metode mana yang sebaiknya digunakan untuk regresi data panel tersebut. Dengan melakukan Chow Test untuk memilih antara metode pooled least square atau fixed effect model. Apabila model fixed effect yang terpilih, maka harus dilakukan pengujian lebih lanjut menggunakan uj Hausman. 
Uji Chow Test, uji dilakukan dengan hipotesis sebagai berikut:

$\mathrm{H}_{0}$ : Metode pooled least square

$\mathrm{H}_{\mathrm{a}}$ : Metode fixed effect

Jika hasil uji diperoleh tingkat signifikansi $<0,05$, artinya hipotesis $\mathrm{H}_{0}$ yang ditolak, dan menerima $\mathrm{H}_{\mathrm{a}}$, dengan kata lain metode fixed effect yang lebih tepat untuk estimasi dalam penelitian ini. Berdasarkan perhitungan uji chow test menunjukkan bahwa nilai signifikansi sebesar 0,2018 lebih besar daripada 0,05 sehingga dapat disimpulkan $\mathrm{H}_{0}$ diterima dan $\mathrm{H}_{\mathrm{a}}$ ditolak. Artinya metode estimasi yang dipilih adalah metode pooled least square, dan tidak dibutuhkan pengujian Hausman lebih lanjut.

\section{Analisis Regresi PLS Perusahaan Manufaktur Australia}

Analisis regresi sederhana dalam penelitian ini dimaksudkan untuk mengetahui pengaruh dari variabel DEF terhadap $\triangle \mathrm{D}$ pada perusahaan manufaktur di Australia selama periode 20062010. Hasil regresi untuk perusahaan manufaktur di Australia ditunjukkan pada Tabel 4.3.

Tabel 4.3

Hasil Regresi Sederhana Perusahaan Manufaktur Australia

\begin{tabular}{ccccc}
\hline \hline Variable & Coefficient & Std. Error & t-Statistic & Prob. \\
\hline \hline C & 0.002541 & 0.013430 & 0.189214 & 0.8501 \\
DEF? & -0.065398 & 0.030070 & -2.174857 & 0.0307 \\
\hline \hline R-squared & 0.020770 & Mean dependent var & 0.010204 \\
Adjusted R-squared & 0.016379 & S.D. dependent var & 0.196009 \\
S.E. of regression & 0.194397 & Sum squared resid & 8.427232 \\
F-statistic & 4.730004 & Durbin-Watson stat & 1.972027 \\
Prob(F-statistic) & 0.030693 & & & \\
\hline \hline
\end{tabular}

Sumber : Hasil Output Eviews 6.0 yang diolah

Berdasarkan Tabel 4.3 nilai konstanta $(\alpha)$ sebesar 0,002541 artinya apabila DEF konstan, maka diprediksi perusahaan akan menerbitkan utang tambahan sebesar 0,002541. Nilai koefisien $(\beta)$ bertanda negatif sebesar 0,065398 menunjukkan perubahan yang tidak searah antara variabel DEF dengan variabel perubahan utang, yang artinya semakin meningkat DEF atau ketika perusahaan membutuhkan dana dari eksternal, semakin menurun perubahan utang perusahaan.

Nilai signifikansi yang lebih kecil dari 0,05 dan nilai t yang negatif, dapat disimpulkan bahwa DEF berpengaruh negatif signifikan terhadap perubahan utang. Hasil analisis regresi yang diperoleh menunjukkan bahwa perusahaan manufaktur di Australia tidak menerapkan pecking order theory. Terdapat berbagai alasan mengapa pecking order theory tidak 
diterapkan dalam penentuan struktur modal di Australia. Pertama, perusahaan-perusahaan di Australia memperluas penggunaan warrant \& right sebagai sumber pendanaan karena warrant \& right memiliki biaya informasi asimetris yang lebih rendah. Kedua, studi yang dilakukan oleh Pattenden (2006) menunjukkan bahwa sistem kredit di Australia menghapuskan keuntungan pajak atas penggunaan utang karena pembayaran bunga dan dividen terbuat dari sebelum pajak pendapatan, sehingga tidak ada pajak ganda atas dividen. Sistem ini menguntungkan pemegang saham Australia dan menyebabkan perusahaan di Australia cenderung tidak menggunakan sumber pendanaan berupa utang. Hasil ini konsisten dengan hasil penelitian sebelumnya di negara maju oleh Frank dan Goyal (2002) bahwa perusahaan di negara Amerika lebih menggunakan dana eksternal berupa penerbitan saham ketika terjadi financing deficit.

\section{Analisis Regresi PLS Perusahaan Manufaktur Indonesia}

Hasil analisis regresi untuk perusahaan manufaktur di Indonesia dipaparkan pada Tabel 4.4 dibawah ini :

Tabel 4.4

Hasil Regresi Sederhana Perusahaan Manufaktur Indonesia

\begin{tabular}{ccccc}
\hline \hline Variable & Coefficient & Std. Error & t-Statistic & Prob. \\
\hline \hline C & 0.008068 & 0.005605 & 1.439502 & 0.1521 \\
DEF? & 0.055536 & 0.025803 & 2.152355 & 0.0330 \\
\hline \hline R-squared & 0.030352 & Mean dependent var & -0.002428 \\
Adjusted R-squared & 0.023800 & S.D. dependent var & 0.162725 \\
S.E. of regression & 0.160781 & Sum squared resid & 3.825880 \\
F-statistic & 4.632631 & Durbin-Watson stat & 2.298953 \\
Prob(F-statistic) & 0.032991 & & \\
\hline \hline
\end{tabular}

Sumber : Hasil output Eviews 6.0 yang diolah

Berdasarkan Tabel 4.4, tampak nilai koefisien $(\beta)$ di Indonesia bertanda positif yang menunjukkan pengaruh perubahan yang searah variabel DEF terhadap variabel perubahan utang. Artinya semakin meningkat DEF semakin meningkat pula penambahan utang perusahaan. Hasil pengujian menunjukkan bahwa nilai uji t variabel DEF dengan nilai signifikansi kurang dari 0,05 yaitu 0,0330 menunjukkan DEF berpengaruh positif signifikan terhadap perubahan utang. Dengan kata lain $\mathrm{H}_{0}$ ditolak atau dapat dikatakan perusahaan manufatur di Indonesia menerapkan pecking order theory dalam penentuan struktur modal.

Hasil regresi perusahaan manufaktur di Indonesia menunjukkan adanya penerapan peckingorder theory dalam penentuan struktur modal. Penggunaan utang didahulukan dibandingkan penerbitan saham di Indonesia, karena perusahaan di Indonesia masih emeroleh manfaat pajak dari penggunaan utang. Selain itu, penerbitan saham membutuhkan biaya yang lebih besar dibandingkan apabila perusahaan menggunakan utang. Sistem hukum yang dianut oleh kedua negara ini berbeda, Indonesia menganut civil law, dan Australia menganut 
common law. Menurut Ball, et al (2000) dan Jalal (2008) negara yang menganut sistem hukum civil law akan cenderung menerapkan pecking order theory dan negara yang menganut sistem hukum common law cenderung tidak menerapkan pecking order theory dalam penentuan struktur modal. Menurut Jalal (2003), negara yang termasuk dalam common law pemegang sahamnya mendapatkan proteksi yang lebih besar dan pelaksanaan hukum yang lebih ketat apabila hak pemegang saham dilanggar.

\section{Simpulan}

Berdasarkan atas hasil pengujian hipotesis yang dilakukan dan pembahasan yang telah dipaparkan pada bagian sebelumnya, maka dapat diambil kesimpulan sebagai berikut :

1. Terdapat perbedaan yang signifikan antara struktur modal perusahaan manufaktur di Indonesia dan di Australia. Di Indonesia menggunakan utang lebih banyak daripada modal sendiri, sedangkan di Australia lebih menggunakan modal sendiri daripada utang.

2. Berdasarkan model Shyam-Sunder dan Myers (1999) hasil analisis menunjukkan bahwa perusahaan manufakttur di Australia tdak menerapkan pecking order theory sedangkan perusahaan manufaktur di Indonesia menerapan pecking order theory dalam penentuan struktur modal. 


\section{DAFTAR PUSTAKA}

Babu, Suresh \& Jain. 1998. Capital Structure Practices of Private Corporate Sector in India, Vol.37. New Delhi: Publication Division

Bambang, Riyanto. 2001. Dasar-Dasar Pembelanjaan Perusahaan. Edisi keempat, Cetakan ketujuh. Yogyakarta: BPFE Yogyakarta

Bhuain, Shahid N. 1997. Marketing Cues and Perceived Quality: Perceptions of Saudi Consumers Towards Products of the US, Japan, Germany, Italy, UK, and France. Journal of Quality Management, 2, pp.217-234

Brealey R. A., et al. 2001. Fundamentals od Corporate Finance. Third Edition. US: McGrawHill Inc.

Brigham, Eugene F. \& Michael C. E. 2001. Manajemen Keuangan, Jilid 1. Edisi kesepuluh. Terjemahan. Jakarta: Salemba Empat

Cassar, et al. 2003. Capital Structure and Financing of SMEs: Australian Evidence. Accounting and Finance Association of Australia and New Zealand, Vol.43 (2), pp.123-147

Chirinko, R.S. \& Singha. 2000. Testing Static Tradeoff Against Pecking Order Models of Capital Structure. Journal of Financial Economics, Vol.58, pp.417-425

Chlarella, Carl, et al. 1991. Determinants of Corporate Capital Structure Australian Evidence. Journal of Financial and Quantitative Analysis, Vol.2, No.20, pp.73-94

Drobetz, et al. 2003. What are the Determinants of the Capital Structure ? Some Evidence for Switzerland. Working Paper, No.4, pp.1-32

------. 2010. International Tests of the Pecking Order Theory. Journal of Financial Economics, No.32, pp.1-47

Frank, Murray Z. \& Vidhan K. Goyal. 2002. Testing the Pecking Order Theory of Capital Structure. Journal of Financial Economics, Vol.67, pp.217-248

Ghazali, Imam. 2009. Aplikasi Analisis Multivariate dengan Program SPSS. Cetakan IV. Semarang: Badan Penerbit Undip.

Glen, Jack \& Ajit Singh. 2003. Comparing Capital Structures and Rates of Return in Developed and Emerging Markets. Emerging Markets Review, 5, pp.161-192

-------. 2004. Capital Structure, Rates of Return, and inaning Corporate Growth: Commparing Developed and Emerging Markets 1994-2000 (Ed.). The Future of Domestic Capital Market in Developing Countries. Washington: Brookings Institution

Huang, Samuel G. H. \& Frank M. Song. 2002. The Determinants of Capital Structure: Evidence from China. Economics and Finance Centre for China Financial Research. pp.1-21 
Hutagaol, Roma Uli. 2002. Pengujian Teori Pecking Order dan Teori Static Trade-Off terhadap Struktur Modal Emiten di Bursa Efek Jakarta. Tesis. Tidak diterbitkan. Magister Manajemen Universitas Indonesia

Myers, S. 2001. Capital Structure. The Journal of Economic Perspectives, Vol.15, No.2, pp.81-102

Myers, S. \& N. Majluf. 1984. Corporate Financing and Investment Decisions When Firms Have Information that Investors Do Not Have. Journal of Financial Economics, Vol.13, pp.187-221

Ni, J. \& M. Yu. 2008. Testing the Pecking Order Theory. The Chinese Economy, Vol.41, pp.97-113

Nugraha, Andi Dwi Kurnia. 2012. Debt Capacity dan Pengujian Teori Pecking Order pada Perusahaan Non-Keuangan yang Terdaftar di Bursa Efek Indonesia Tahun 2006-2010. Skripsi. Tidak diterbitkan. Fakultas Ilmu Sosial dan Ilmu Politik Universitas Indonesia Depok.

Pattenden, K. 2006. Capital Structure Decisions Under Classical and Imputation Tax Systems: A Natural Test for Tax Effects in Australia. Australian Journal of Management, 31(1), 67-92

Rodoni, Ahmad \& Herni Ali. 2010. Manajemen Keuangan. Jakarta: Mitra Wacana Media

Ross, Stephen A., Randolph W. Westerfield, Bradford D. Jordan. 2009. Pengantar Keuangan Perusahaan. Buku 2. Edisi kedelapan. Terjemahan. Jakarta: Salemba Empat

Singh, A. \& Hamid J. 1992. Corporate Financial Structures in Developing Countries. IFC Technical Paper, No.1

Singh, A. 1995. Corporate Financing Patterns in Industrializing Economies: A Comparative International Study. IFC Technical Paper, No.2

Shyam-Sunder, L. \& Myers. 1999. Testing Static Tradeoff Against Pecking Order Models of Capital Structure. Journal of Financial Economics, Vol.51, pp.219-244 